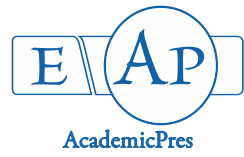

\title{
Influence of Magnetized Water and Seed on Yield and Uptake of Heavy Metals of Tomato
}

\author{
Kamorudeen Olaniyi YUSUF ${ }^{1 *}$, Shakiru Ariyo SAKARIYAH ${ }^{1}$, \\ Modupe Ruth BAIYERI ${ }^{2}$ \\ ${ }^{1}$ University of Ilorin, Department of Agricultural and Biosystems Engineering, Ilorin, Kwara State, Nigeria; kamaru.yusuf@yahoo.com \\ (*correspondingauthor);yusuf.ok@unilorin.edu.ng; ebonyalhajy@gmail.com \\ ${ }^{2}$ Institute of Technology, Department of Agricultural and Bio-Environmental Engineering Technology, Kwara State Polytechnic, Ilorin, Nigeria; \\ baiyerimodupe@gmail.com
}

\begin{abstract}
This study assessed influence of magnetized water (MW) and magnetized seed (MS) on yield and uptake of heavy metals of tomato. Tomato seeds were put on permanent magnet (1000 gauss) for 24 hours and water was allowed to flow through magnetic flux density 319 gauss. Tomato seeds (variety UC82B) were planted in 16 pots, thinned after 21 days to one tomato/pot and irrigated with MW or non-magnetized water (NMW). Four treatments used were MS and MW $\left(\mathrm{T}_{1}\right)$, nonmagnetized seed (NMS) and MW ( $\left.\mathrm{T}_{2}\right)$, MS and NMW ( $\left.\mathrm{T}_{3}\right)$, NMS and NMW ( $\left.\mathrm{T}_{4}\right)$. A 1.0 litre of water was applied to tomato plant in a completely randomized design and each treatment was replicated 4 times. Yields and concentrations of cadmium, copper, chromium, iron, manganese, nickel, lead and zinc were determined from the tomato fruit. The mean yields for $T_{1}, T_{2}$, $\mathrm{T}_{3}$ and $\mathrm{T}_{4}$ were $288.1,275.8,176.6$ and $200.1 \mathrm{~g} /$ pot, respectively. Mean concentrations of Iron for $\mathrm{T}_{1}, \mathrm{~T}_{2}, \mathrm{~T}_{3}$ and $\mathrm{T}_{4}$ were $0.015,0.010,0.010$ and $0.010 \mathrm{mg} / \mathrm{L}$, respectively. Mean concentrations of zinc for $\mathrm{T}_{1}, \mathrm{~T}_{2} \mathrm{~T}_{3}$ and $\mathrm{T}_{4}$ were $0.030,0.110,0.115$ and $0.125 \mathrm{mg} / \mathrm{L}$. The values of copper, iron, lead, manganese and zinc for $\mathrm{T}_{2}$ were $0.02-0.03,1.2-1.8,0.03-0.07,0.10-0.12$ and 0.00-0.01 mg/L. The corresponding values for $\mathrm{T}_{4}$ were $0.02-0.02,1.30-1.60,0.04-0.04,0.08-0.11 \mathrm{mg} / \mathrm{L}$ but $\mathrm{Zn}$ was not detected. Concentrations of heavy metals in the tomato were below FAO/WHO permissible limits. MW and MS increased tomato yield and didn't increase uptake of heavy metals that could cause diseases to man.
\end{abstract}

Keywords: heavy metals in tomato; irrigation; magnetized water; pair t-test; tomato quality

\section{Introduction}

Magnetized water also called magnetically treated water or magnetic treatment of water is the water that has passed through magnetic field. It is a non-chemical method and environmentally-friendly that boosts crop yield (Maheshwari and Grewal, 2009; Babu, 2010; Yusuf and Ogunlela, 2017a). It also improves crop quality, increased minerals dissolvability of water for calcium, nitrogen, potassium, iron and lead which could enhance nutrients uptake of crops (Selim, 2008; Babu, 2010; Hozayn and Abdul-Qados, 2010). Magnetically treated water increased nutritional quality of tomato such as vitamin $\mathrm{A}$, vitamin $\mathrm{C}$ and slightly increased uptake of lead content (Yusuf and Ogunlela, 2016). Yusuf and Ogunlela (2017b) pointed out that magnetic treatment of irrigation water (magnetized water) increased the rate of water absorption by plant for evapotranspiration which eventually increased the rate of vegetative growth of tomato plant, nutrient uptake and the yield. Rawabdeh et al. (2014) pointed out that magnetically treated water significantly increased essential elements such as nitrogen, phosphorus and potassium uptake and their translocation when compared with plants irrigated with tap water that was non magnetically treated water. Othman $e t$ al. (2009) also pointed out that magnetic treatment of landfill leachate improved the removal of suspended solid, chemical oxygen demand and biochemical oxygen demand by 60 to $80 \%$ using a magnetic field strength of $0.55 \mathrm{~T}$ (5,500 gauss).

Magnetically treated water enhanced uptake of potassium and phosphorous which are needed for the plant cell's chemical reactions that are essential for the formation and movement of carbohydrates, development of roots which are necessary for absorption of minerals, water and ATP (adenosine triposphate) which is a basic molecule of energy and nucleic acids (Yano et al., 2004; Taia et al., 2007). ELshokali and Abdelbagi (2014) also concluded that 
magnetized water improved the calcium, iron, potassium and zinc contents in seeds of onion, sunflower and tomato fruit which significantly increased the production quality of the plants compared to non-magnetized water.

Magnetized water has ability to stimulate defense system, produced photosynthetic activity, and increased translocation efficiency of photoassimilates in common bean plants (Moussa, 2011). The uptake of the some elements such as nitrogen, calcium, sulphur and phosphorus by crops irrigated with magnetized water could improve the nutritional quality (like protein and vitamin $\mathrm{C}$ contents).

A few heavy metals such as lead, copper, manganese, zinc, iron and chromium and nickel are essential for plant metabolism in trace amounts but they become toxic to plant and animal when they are available in excess and above WHO (World Health Organisation) permissible limits (Rawabdeh et al., 2014). Magnetized water increased crop yield and enhanced nutrients uptake (Maheshwari and Grewal, 2009; Babu, 2010; Rawabdeh et al., 2014) but if magnetized water increased uptake of heavy metals above the permissible limits, it could cause certain diseases such as cancer, neurological disorder, hypertension and gastrointestinal disorder to man. There is need to determine the effect of magnetized water on the uptake of heavy metals by some crops to prevent some diseases which could affect man due consumption of crops produced with magnetized water.

The north and south poles of the electromagnetic cores on the treatment pipe should be alternated for effective treatment of the irrigation water by the magnetic field as stated by (McMahon, 2006). Maheshwari and Grewal (2009) used magnetic flux density between 35 and 1360 gauss $(\mathrm{G})$ which was measured inside the pipe. Podlesny et al. (2004) pointed out that the residence time for treatment of irrigation water in magnetic field should be $15 \mathrm{~s}$ while Aladjadjiyan (2007) indicated that 60 to $600 \mathrm{~s}$ was appropriate for effective magnetic treatment of water. The objective of this study was to determine the influence of magnetized water and magnetized seed on the yield and uptake of heavy metals from tomato fruit.

\section{Materials and Methods}

\section{Location of the study}

The study was carried out at the Research Farm of the Department of Agricultural and Biosystems Engineering, University of Ilorin, Ilorin, Kwara State, Nigeria between $23^{\text {rd }}$ December, 2016 and $15^{\text {th }}$ July, 2017. Ilorin lies on the latitude $8^{\circ} 30^{\prime} \mathrm{N}$ and longitude $4^{\prime} 35^{\prime} \mathrm{E}$ at an elevation of about $340 \mathrm{~m}$ above mean sea level (Ejieji and Adeniran, 2009). Ilorin is in the Southern Guinea Savannah Ecological Zone of Nigeria with annual rainfall of about $1300 \mathrm{~mm}$. The wet season begins towards the end of March and ends in October while the dry season starts in November and ends in March (Ogunlela, 2001). The experiment for this study to determine if magnetized water and magnetized seed could increase uptake of heave metals was conducted twice to have a reliable results.
Determination of crop evapotranspiration, water requirement and irrigation interval

Water requirement of tomato plant is the amount of water required to meet the required evapotranspiration, photosynthesis and metabolic processes. Crop evapotranspiration, depth of water required to bring the soil to field capacity at the beginning of the experiment, available water, wilting point, net depth of irrigation, irrigation interval and volume of water required daily by tomato plant and volume of water required in three (3) days irrigation interval by the tomato plant were determined using Equations (1), (2), (3), (4), (5), (6), (7) and (8), respectively:

$$
\begin{aligned}
& \text { (1) } E T_{c}=k_{c} \times E T_{o} \\
& \text { (2) } A W=\frac{\rho_{b}}{\rho_{w}}\left(\frac{F C-W P}{100}\right) D_{b} \\
& \text { (3) } W P=\frac{F C}{F} \\
& \text { (4) } d_{n}=P_{n} \times A W \\
& \text { (5) } I_{v}=\frac{d_{n}}{E T_{c}} \\
& \text { (6) } V_{d}=C_{c} \times A_{b} \times E T_{c} \\
& \text { (7) } V_{i}=C_{c} \times A_{b} \times E T_{c} \times I_{v} \times N_{p}
\end{aligned}
$$

where $\mathrm{ET}_{\mathrm{c}}$ is the crop evapotranspiration $(\mathrm{mm} / \mathrm{day}), \mathrm{k}_{\mathrm{c}}$ is the crop coefficient, $\mathrm{ET}_{\mathrm{o}}$ is the reference evapotranspiration $(\mathrm{mm} /$ day $), D_{F}$ is the depth of water required to bring moisture content to $\mathrm{FC}$ at the beginning of the experiment $(\mathrm{mm}), \mathrm{pb}$ is the soil bulk density $\left(\mathrm{g} / \mathrm{cm}^{3}\right)$, $\rho_{w}$ is the density of water $\left(\mathrm{g} / \mathrm{cm}^{3}\right), F C$ is the field capacity of the soil (\%), $\Theta$ is the initial moisture content of the soil prior to irrigation (\%), $\mathrm{D}_{\mathrm{b}}$ is the depth of the bucket or pot $(\mathrm{mm})$, Aw is the available water $(\mathrm{mm})$, WP is the wilting point $(\%), I_{v}$ is the irrigation interval (day), $d_{n}$ is the net depth of irrigation $(\mathrm{mm}), \mathrm{P}_{\mathrm{n}}$ is the percentage of available water supply during irrigation (fraction, $50 \%=0.5$ ), $\mathrm{C}_{c}$ is the crop canopy but taken as $100 \%(1), V_{d}$ is the volume of water required by tomato plant (litre/day), $A_{b}$ is the area of the bucket $\left(\mathrm{m}^{2}\right), \mathrm{N}_{\mathrm{p}}$ is the number of plants that are to be irrigated and $\mathrm{V}_{\mathrm{i}}$ is the volume of water required by plant per irrigation (litre).

$\mathrm{F}$ in equation (4) is a factor ranging from $2.0-2.4$ depending on the percentage of silt in the soil (Sani, 2003). The value of F used was 2.2 and WP was calculated to be $12.26 \%$ when FC was $26.98 \%$. The values of crop coefficient $\left(\mathrm{k}_{\mathrm{c}}\right)$ used was 1.15 because Ufoegbune et al. (2012) indicated that $\mathrm{k}_{\mathrm{c}}$ of tomato at flowering stage was 1.15. Reference evapotranspiration $\left(\mathrm{ET}_{\mathrm{o}}\right)$ of Ilorin for the North Central zone from the graph by Chineke et al. (2011) for peak value during the month of March of the year is $5.5 \mathrm{~mm} /$ day and it was used in this study and $A_{b}$ of the bucket (pot) was equal to $0.05433 \mathrm{~m}^{2}$. 
124

\section{Chemical properties of soil used}

The chemical properties of soil used in the study are presented in Table 1. Sample A was the chemical properties of soil used in the first experiment which was conducted between $23^{\text {rd }}$ December, 2016 and $18^{\text {th }}$ March, 2017 (85 days) in which the tomato yield was not considered in the study but concentrations of some heavy metals in the tomato fruit were determined. Sample B was the chemical properties of soil used in the second experiment that was conducted between $23^{\text {rd }}$ March and $15^{\text {th }}$ July, 2017, which lasted for 114 days. Tomato yield and concentrations of some selected heavy metals in the tomato fruit were determined in the second experiment.

Treatment of the water by magnetic field and chemical properties of water used

The water used in this study was fetched from University of Ilorin dam (at downstream, about $80 \mathrm{~m}$ away from the dam). The chemical properties of the water were presented in Table 2. The irrigation water was allowed to pass through a magnetic flux density of 319 gauss $(31.9 \mathrm{mT})$ for about $113 \mathrm{~s}$. The magnetic field was produced by electromagnet designed for treating the irrigation as shown in Figs. 1 and 2. The equivalent magnetic flux density between two magnetic cores without air gap was 1,684 gauss. The magnetic flux density was measured inside the rectangular treatment pipe in which 2 magnetic cores was $20 \mathrm{~mm}$ away from each other using a gaussmeter, Model GM-2 by Alpha Lab Inc. Water samples were taken from magnetized and non-magnetized water for chemicals analysis and the concentrations of some selected heavy metals were analyzed as shown in Table 2. A 1.0 litre of magnetized or non-magnetized water was carefully applied to the soil in each pot containing tomato plant at 3 days interval during the vegetative growth but the irrigation interval was reduced to 2 days during the flowering/fruiting stage of the tomato plant to avoid water stress which could affect the tomato yield. The electromagnetic treatment device was developed locally in Ilorin using readily available materials mainly $2.19 \mathrm{~mm}$ thick copper wire (gauge 15) and transformer from worn-out uninterrupted power supply (UPS) as the core after the supporting sides of it were cut off and the coils (primary and secondary coils) were also removed. A new winding of 180 turns was made on each of the twenty (20) lamination cores with the copper wire. The rectangular pipe was 20 by $50 \mathrm{~mm}$ (but internal dimension was 15 by $46 \mathrm{~mm}$ ) and $3 \mathrm{~m}$ long constructed from a transparent perspex glass of thickness $2 \mathrm{~mm}$.

Table 1. Chemical properties of the soil used

\begin{tabular}{ccc}
\hline Element & Sample A & Sample B \\
\hline $\mathrm{pH}$ & 4.70 & 5.30 \\
$\mathrm{~N}(\%)$ & 0.80 & 1.00 \\
$\mathrm{P}(\mathrm{mg} / \mathrm{L})$ & 0.39 & 0.22 \\
$\mathrm{~K}^{+}(\mathrm{mg} / \mathrm{L})$ & 0.11 & 0.13 \\
$\mathrm{~Pb}^{2+}(\mathrm{mg} / \mathrm{L})$ & 1.80 & 1.30 \\
$\mathrm{Zn}^{2+}(\mathrm{mg} / \mathrm{L})$ & 0.90 & 0.80 \\
$\mathrm{Cr}^{2+}(\mathrm{mg} / \mathrm{L})$ & 0.14 & 0.07 \\
$\mathrm{Cu}^{2+}(\mathrm{mg} / \mathrm{L})$ & 0.54 & 0.55 \\
$\mathrm{Cd}^{2+}(\mathrm{mg} / \mathrm{L})$ & 0.01 & 0.01 \\
$\mathrm{Fe}^{2+}(\mathrm{mg} / \mathrm{L})$ & 8.50 & 8.70 \\
$\mathrm{Mn}^{2+}(\mathrm{mg} / \mathrm{L})$ & 0.55 & 0.60 \\
\hline
\end{tabular}

Table 2. Concentrations of some selected heavy metals in the water used for irrigation

\begin{tabular}{cccc}
\hline Element & WHO limits (2003) & MTW & NMTW \\
\hline $\mathrm{Pb}^{2+}(\mathrm{mg} / \mathrm{L})$ & 5.00 & $\mathrm{ND}$ & ND \\
$\mathrm{Zn}^{2+}(\mathrm{mg} / \mathrm{L})$ & 2.00 & $\mathrm{ND}$ & $\mathrm{ND}$ \\
$\mathrm{Cr}^{2+}(\mathrm{mg} / \mathrm{L})$ & 1.00 & $\mathrm{ND}$ & $\mathrm{ND}$ \\
$\mathrm{Cu}^{2+}(\mathrm{mg} / \mathrm{L})$ & 0.20 & $\mathrm{ND}$ & $\mathrm{ND}$ \\
$\mathrm{Cd}^{2+}(\mathrm{mg} / \mathrm{L})$ & 0.01 & $\mathrm{ND}$ & $\mathrm{ND}$ \\
$\mathrm{Fe}^{2+}(\mathrm{mg} / \mathrm{L})$ & 5.00 & $\mathrm{ND}$ & 0.10 \\
$\mathrm{Mn}^{2+}(\mathrm{mg} / \mathrm{L})$ & 0.26 & $\mathrm{ND}$ & $\mathrm{ND}$ \\
\hline
\end{tabular}

$\overline{\mathrm{WHO}}=$ World Health Organization, $\mathrm{ND}=$ Not detected

MW = Magnetized water, NMW $=$ Non-magnetized water 


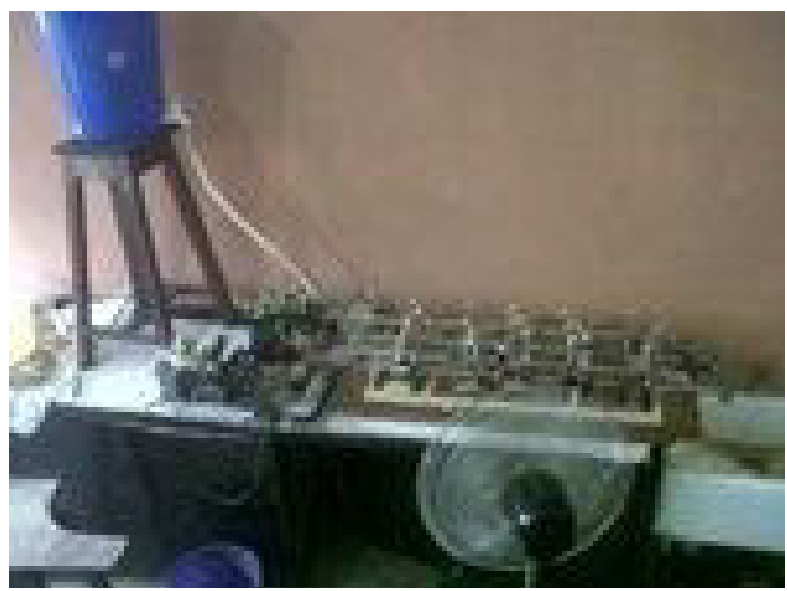

Fig. 1. Electromagnetic treatment device

\section{Parameters analysed}

Two samples of tomato were randomly harvested from $T_{1}, T_{2}, T_{3}$ and $T_{4}$ after 95 days (for the second experiment) but 85 days (for the first experiment) for the determination of concentrations of some selected heavy metals in the tomato.

Determination of concentrations of lead and other heavy metals

The tomato was ground (wet tomato paste) and sieved through $2 \mathrm{~mm}$ sieve. A $2 \mathrm{~g}$ of the sample was weighed and heated to dryness in a well-cleaned porcelain crucible between 450 and $500{ }^{\circ} \mathrm{C}$ in a hot plate. The ash content was then dissolved in $5 \mathrm{ml} \mathrm{HNO}, \mathrm{HCL}$ and $\mathrm{H}_{2} \mathrm{O}$ in ratio of $1: 2: 3$, respectively and this was heated on a hot plate until brown fume disappeared. A $5 \mathrm{ml}$ of deionized water was added and heated until a colorless solution was obtained. The mineral solution was transferred into $100 \mathrm{ml}$ volumetric flask and filtered through Whatman No 42 filter paper. This solution was then analyzed by Atomic Absorption Spectrophotometer (AAS) as given by AOAC (2000). The same procedure was used for digestion process and AAS was used to analyze other heavy metals as given by AOAC (2000).

Statistical analysis by Completely Randomized Design

Statistical analysis on the yield of tomato was computed to determine if the influence of magnetized seed and magnetized water was statistically significant on the tomato yield or not using Completely Randomized Design (CRD). Sum of square treatment $\left(S S T_{R}\right)$, Sum of square total $\left(\mathrm{SST}_{\mathrm{O}}\right)$ correction factor (C.F) and sum of square error $\left(\mathrm{SS}_{\mathrm{E}}\right)$ were computed using Equations (9), (10), (11) and (12), respectively. The Analysis of Variance (ANOVA) was based on values generated from Equations (9), (10) and (12).

$$
\begin{aligned}
& \text { (8) } S S T_{R}=\frac{\sum T_{i}^{2}}{t}-C . F \\
& \text { (9) } S S T_{O}=\sum X_{i}^{2}-C . F \\
& \text { (10) } C . F=\frac{G^{2}}{N}
\end{aligned}
$$

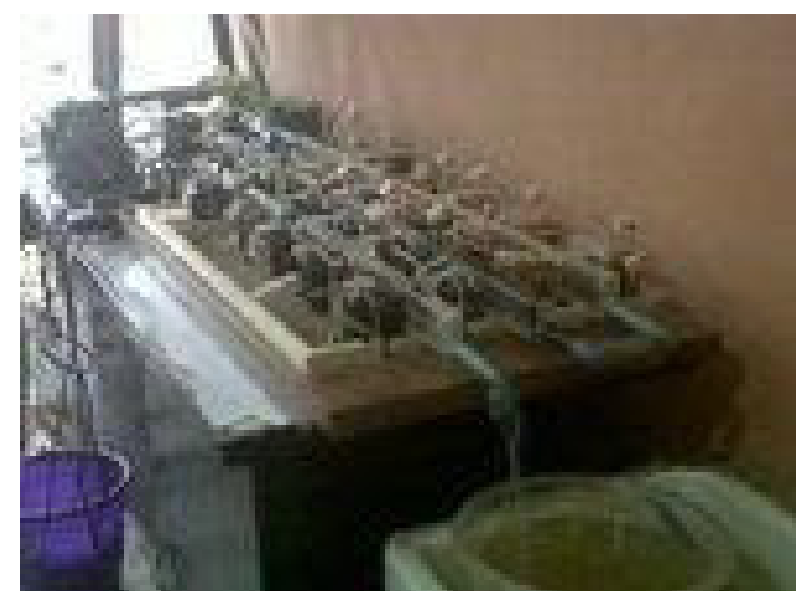

Fig. 2. Magnetized water from the electromagnet

(11) $S S_{E}=S S T_{O}-S S T_{R}$

where $T_{i}$ is the total yield of each treatment, $t$ is the number of treatments used, $\mathrm{X}$ is the individual yield based on the treatment used, $G$ is the total yield from all the treatments used and $\mathrm{N}$ is the number of observation which is equal to the product of number of treatments $(t)$ and number replications $(\mathrm{r})$ or $(\mathrm{t} \times \mathrm{r})$.

\section{Statistical analysis by pair t-test}

A pair $\mathrm{t}$-test statistical analysis was also computed between $T_{1}$ versus $T_{4}$ and $T_{2}$ versus $T_{4}$. The difference between the two mean of the results was determined and used to compute the standard deviation, standard error and t-test value using equations (13), (14a) or (14b), (15) and (16), respectively as given by Montgomery (1998). The calculated values of the $t$-test and that of table values were shown in Table 3.

$$
\begin{aligned}
& \text { (12) } \bar{d}=\frac{\sum d}{n} \\
& \text { (13a) } \delta=\sqrt{\frac{\sum(d-\bar{d})^{2}}{n-1}} \\
& \text { (13b) } \delta=\sqrt{\frac{\sum d^{2}-n(\bar{d})^{2}}{n-1}} \\
& \text { (14) } \delta_{E r}=\frac{\delta}{\sqrt{n}} \\
& \text { (15) } t_{c a l}=\frac{\delta_{E r}}{\delta_{E r}}
\end{aligned}
$$

where $\mathrm{d}$ is the mean of the difference from the data $\mathrm{x}_{1}$ and $\mathrm{x}_{2}, \Sigma \mathrm{d}$ is the summation of $\mathrm{d}, \mathrm{n}$ is the number of the treatments (observations), $\delta$ is the standard deviation, $\delta_{\mathrm{Er}}$ is the standard error and $t_{\text {cal }}$ is the calculated value of $t$ which was compared with the table value of $\mathrm{t}_{\mathrm{Tab}}$ at $\alpha=5 \%$ significant level but $2.5 \%(\alpha=0.05 / 2=0.025)$ for paired $t$ test. For example, the tomato yield between $T_{2}$ and $T_{4}$ extracted from Table 4 for pair t-test was computed as follows for $T_{2}$ versus $T_{4}$. 
126

Table 3. Data of tomato yield for computation of pair t-test

\begin{tabular}{|c|c|c|c|}
\hline $\mathrm{T}_{2}(\mathrm{NMS}+\mathrm{MW})$ & $\mathrm{T}_{4}(\mathrm{NMS}+\mathrm{NMW})$ & $\mathrm{d}=\mathrm{T}_{1}-\mathrm{T}_{2}$ & $d^{2}$ \\
\hline 168.9 & 165.4 & 3.5 & 12.25 \\
\hline 390.7 & 305.2 & 85.5 & $7,310.25$ \\
\hline 231.8 & 146.6 & 65.2 & $7,259.04$ \\
\hline 311.6 & 183.2 & 128.4 & $16,486.56$ \\
\hline $\mathrm{n}=4$ & & $\Sigma d=302.6$ & $\Sigma d^{2}=31068.10$ \\
\hline
\end{tabular}

$\bar{d}=\frac{302.6}{4}=75.65$

$\delta=\sqrt{\frac{31068.10-4(75.65)^{2}}{4-1}}=52.21$

$\delta_{E r}=\frac{52.21}{\sqrt{4}}=26.10$

$t_{c a l}=\frac{75.65}{26.10}=2.898$

\section{Results and Discussion} tomato

Effect of magnetized water and magnetized seed on yield of

The total and mean yields of tomato plant irrigated by magnetized seed and magnetized water $\left(T_{1}\right)$, nonmagnetized seed and magnetized water $\left(T_{2}\right)$, magnetized seed and non-magnetized water $\left(\mathrm{T}_{3}\right)$, non-magnetized seed and non-magnetized water $\left(\mathrm{T}_{4}\right)$ were presented in Table 4. The mean yields of tomato for $T_{1}, T_{2}, T_{3}$ and $T_{4}$ were 288.1, $275.8,176.6$ and $200.1 \mathrm{~g} /$ pot, respectively. The interaction of magnetized seed and magnetized water produced the highest yield of tomato fruit which means that magnetic field had positive effect on the seed but magnetized water had more influence on the tomato yield than the magnetized seed. Interaction of non-magnetized seed and magnetized water produced higher yield than the interaction of non-magnetized seed and non-magnetized water.

The highest yield of tomato was obtained with the tomato plant irrigated with magnetized water and magnetized seed $\left(T_{1}\right)$ and the yield were followed by nonmagnetized seed and magnetized water $\left(T_{2}\right)$. This was in agreement with the yield obtained by Ali (2004) that interaction of magnetized seed and magnetized water produced the highest yield. Generally, magnetized water and non-magnetized seed increased the tomato yield than the non-magnetized water and non-magnetized seed. This was also in agreement with the results obtained by Alderfasi et al. (2016) that magnetic treatment of irrigation water increased biomass and yield of wheat, Barley and triticale crops. The influence of $T_{1}, T_{2}, T_{3}$ and $T_{4}$ was not statistically significant on tomato yield because the calculated value of $\mathrm{F}$ was 1.859 while the table value was 3.49 $(1.859<3.49)$ as shown in ANOVA Table 5 for the CRD. In addition to that, statistical analysis on the tomato yield using pair t-test for $T_{1}$ versus $T_{4}$, and $T_{2}$ versus $T_{4}$, the calculated value of t-test were 1.091 and 2.898 , respectively but table value of t-test at $\alpha=5 \%(\alpha=0.05)$ but for pair $\mathrm{t}$ test $\alpha=2.5 \%(\alpha=0.025)$ and at 3 degree of freedom was 4.176. This means that the influence of magnetized seed and water were not statistically significant on the yield of tomato in this study because calculated value of pair t-test 1.091 and 2.898 were less than the table value 4.176 though the technology (magnetic treatment of irrigation water) increased yield of tomato and a good technology for crops production (Maheshwari and Grewal, 2009; Babu, 2010; Moussa, 2011).

Table 4. Total and mean yields of tomato

\begin{tabular}{|c|c|c|c|c|}
\hline \multirow{2}{*}{ Row } & \multicolumn{4}{|c|}{ Total and mean yield of tomato $(\mathrm{g} / \mathrm{pot})$} \\
\hline & $\mathrm{T}_{1}$ & $\mathrm{~T}_{2}$ & $\mathrm{~T}_{3}$ & $\mathrm{~T}_{4}$ \\
\hline 1 & 398.8 & 168.9 & $148.1^{*}$ & 165.4 \\
\hline 2 & 201.2 & 390.7 & 217.1 & 305.2 \\
\hline 3 & 355.0 & 231.8 & 179.3 & 146.6 \\
\hline 4 & 197.4 & 311.6 & $161.7^{*}$ & 183.2 \\
\hline Total yield & 1152.4 & 1103.0 & 706.2 & 800.4 \\
\hline Mean yield & 288.1 & 275.8 & 176.6 & 200.1 \\
\hline
\end{tabular}

* = tomato plant with one branch of the stem was broken by wind (storm) which affected the yield

$\mathrm{T}_{1}=\mathrm{MS}+\mathrm{MW}$ (Magnetized Seed and Magnetized Water)

$\mathrm{T}_{2}=\mathrm{NMS}+\mathrm{MW}$ (Non-Magnetized Seed and Magnetized Water)

$\mathrm{T}_{3}=\mathrm{MS}+\mathrm{NMW}$ (Magnetized Seed and Non-Magnetized Water)

$\mathrm{T}_{4}=\mathrm{NMS}+\mathrm{NMW}$ (Non-Magnetized Seed and Non-Magnetized Water)

Table 5. Analysis of variance (ANOVA) of the tomato yield using CRD

\begin{tabular}{ccccc}
\hline Source of error & Degree of freedom (D.F) & Sum of square (SS) & Mean square (MS) & Calculated F \\
\hline Treatment & 3 & $36,458.09$ & $12,152.70$ & $1.859^{\text {NS }}$ \\
Error & 12 & $48,435.20$ & 6535.17 & 3.49 \\
Total & 15 & $114,435.29$ & & \\
\hline NS = Not significant & & &
\end{tabular}


Influence of magnetized water and seed on uptake of heavy metals by tomato

Uptake of heavy metals by the tomato was assessed based on the concentration of heavy metals in the tomato fruit. In the first experiment conducted between $23^{\text {rd }}$ December, 2016 and $18^{\text {th }}$ March, 2017, the mean concentrations of cadmium, copper, chromium, iron II, lead, manganese and zinc for combination of nonmagnetized seed and magnetized water at $100 \%$ and $80 \%$ of water requirement supplied versus corresponding concentrations of heavy metals for the combination of nonmagnetized seed and non-magnetized water were presented in Table 6. The concentrations of heavy metals in the second experiment for the combinations of magnetized seed and magnetized water as $T_{1}$, non-magnetized seed and magnetized water as $T_{2}$, magnetized seed and nonmagnetized water as $T_{3}$ and non-magnetized seed and nonmagnetized water as $T_{4}$ were presented in Table 7.

In the first experiment with the results shown in Table 6 , cadmium and chromium were not detected (negligible) but values of copper, iron, lead, manganese and zinc with MW for $T_{1}$ and $T_{2}$, the range were $0.02-0.03,1.2-1.8,0.03$ $0.07,0.10-0.12$ and $0.00-0.01 \mathrm{mg} / \mathrm{L}$, respectively. The corresponding values for NMW were 0.02-0.02, 1.30-1.60,
0.04-0.04, $0.08-0.11 \mathrm{mg} / \mathrm{L}$ and $\mathrm{Zn}$ was not detected (negligible). In the second experiment in Table 7, the concentrations of Lead for $T_{1}, T_{2}, T_{3}$ and $T_{4}$ were 0.015 , $0.010,0.010$ and $0.010 \mathrm{mg} / \mathrm{L}$, respectively. The mean concentrations of zinc in the tomato for $T_{1}, T_{2}, T_{3}$ and $T_{4}$ were $0.030,0.110,0.115$ and $0.125 \mathrm{mg} / \mathrm{L}$, respectively. The mean concentrations of cadmium, copper, manganese and nickel in tomato $T_{1}, T_{2}, T_{3}$ and $T_{4}$ were not detected. The combination of magnetized seed and magnetized water slightly influenced or increased uptake of iron II in the two experiments by 11.1 to $33.3 \%$ when $100 \%$ of water requirement was supplied. This results obtained was in agreement with results obtained by Rawabdeh et al. (2014) that magnetically-treated water (magnetized water) increased nitrogen, phosphorous and potassium uptake and their translocation in plant. Mohammed and Ebead (2013) also concluded that magnetically-treated irrigation water increased available soil phosphorous in celery and snow pea. Similarly, magnetized water slightly increased uptake and concentration of Lead in tomato fruit as pointed out by Rawabdeh et al. (2014) and Yusuf and Ogunlela (2016) especially when irrigation water was supplied at $80 \%$ instead of $100 \%$ water requirement. The higher concentrations of some heavy metals in the tomato fruit irrigated with

Table 6. Concentrations of heavy metals in the tomato in the first experiment

\begin{tabular}{|c|c|c|c|c|c|c|c|}
\hline \multirow{2}{*}{ Heavy metal } & \multicolumn{2}{|c|}{ Magnetized water, mg/L } & \multicolumn{2}{|c|}{ Non magnetized water, $\mathrm{mg} / \mathrm{L}$} & \multirow{2}{*}{$\begin{array}{c}\text { WHO } \\
\text { Limits (2003) }\end{array}$} & \multirow{2}{*}{$\begin{array}{c}\text { FAO Limits } \\
(1985)\end{array}$} & \multirow{2}{*}{$\begin{array}{l}\text { Health implication on man according to SON } \\
\text { Act } 2007\end{array}$} \\
\hline & $\mathrm{T}_{1}$ & $\mathrm{~T}_{2}$ & $\mathrm{~T}_{1}$ & $\mathrm{~T}_{2}$ & & & \\
\hline Cadmium & ND & ND & ND & ND & 0.01 & 0.01 & Toxic to kidney \\
\hline Copper & 0.02 & 0.03 & 0.02 & 0.02 & 0.20 & 0.20 & Gastrointestinal disorder \\
\hline Chromium & ND & ND & ND & ND & 1.00 & 1.00 & Cancer \\
\hline Iron II & 1.80 & 1.20 & 1.60 & 1.30 & 5.00 & 5.00 & None \\
\hline Lead & 0.03 & 0.07 & 0.04 & 0.04 & 5.00 & 5.00 & $\begin{array}{l}\text { Cancer, mental retardation in infant, toxic to } \\
\text { central and peripheral nervous systems }\end{array}$ \\
\hline Manganese & 0.12 & 0.10 & 0.08 & 0.11 & 0.26 & - & Neurological disorder \\
\hline Nickel & ND & ND & ND & ND & 1.00 & 0.20 & Possible carcinogenic \\
\hline Zinc & 0.01 & ND & ND & ND & 2.00 & 2.00 & None \\
\hline
\end{tabular}

$\mathrm{T}_{1}=100 \%$ of water requirement was supplied, $\mathrm{T}_{2}=80 \%$ of water requirement was supplied; ND $=$ Not detected, SON $=$ Standards Organization of Nigeria for Drinking Water Quality; FAO = Food and Agriculture Organization of the United Nations; WHO = World Health Organization

Table 7. Concentrations of heavy metals in the tomato in the second experiment

\begin{tabular}{|c|c|c|c|c|c|c|}
\hline \multirow[t]{2}{*}{ Heavy metal } & \multicolumn{6}{|c|}{ Concentration of heavy metals in the tomato $(\mathrm{mg} / \mathrm{L})$} \\
\hline & $\mathrm{T}_{1}$ & $\mathrm{~T}_{2}$ & $\mathrm{~T}_{3}$ & $\mathrm{~T}_{4}$ & WHO limits (2003) & FAO limits (1985) \\
\hline \multirow{2}{*}{ Copper } & ND & ND & ND & ND & \multirow{2}{*}{0.20} & \multirow{2}{*}{0.20} \\
\hline & ND & ND & ND & ND & & \\
\hline \multirow{2}{*}{ Chromium } & ND & ND & ND & ND & \multirow{2}{*}{1.00} & \multirow{2}{*}{1.00} \\
\hline & ND & ND & ND & ND & & \\
\hline \multirow[t]{2}{*}{ Iron II } & 0.010 & 0.010 & 0.010 & 0.010 & \multirow{3}{*}{5.00} & \multirow{3}{*}{5.00} \\
\hline & 0.020 & 0.010 & 0.010 & 0.010 & & \\
\hline Mean & 0.015 & 0.010 & 0.010 & 0.010 & & \\
\hline \multirow{2}{*}{ Manganese } & ND & ND & ND & ND & \multirow{2}{*}{0.26} & \multirow{2}{*}{-} \\
\hline & ND & ND & ND & ND & & \\
\hline \multirow{2}{*}{ Nickel } & ND & ND & ND & ND & \multirow{2}{*}{0.01} & \multirow{2}{*}{0.01} \\
\hline & ND & ND & ND & ND & & \\
\hline \multirow[t]{2}{*}{ Lead } & 0.010 & 0.010 & 0.010 & 0.010 & \multirow{3}{*}{5.00} & \multirow{3}{*}{5.00} \\
\hline & 0.020 & 0.010 & 0.010 & 0.010 & & \\
\hline Mean & 0.015 & 0.010 & 0.010 & 0.010 & & \\
\hline \multirow[t]{2}{*}{ Zinc } & 0.050 & 0.110 & 0.110 & 0.140 & \multirow{3}{*}{2.00} & \multirow{3}{*}{2.00} \\
\hline & 0.010 & 0.110 & 0.120 & 0.110 & & \\
\hline Mean & 0.030 & 0.110 & 0.115 & 0.125 & & \\
\hline
\end{tabular}

(Magnetized Seed and Non-Magnetized Water); T4 = NMS + NMW (Non-Magnetized Seed and Non-Magnetized Water) 
128

magnetized water were in agreement with the results obtained by Babu (2010) that magnetically-treated water increased dissolvability of water for plant minerals and increased nutrients uptake by plant. Concentrations of the heavy metals in the tomato fruits with $T_{1}, T_{2}, T_{3}$ and $T_{4}$ were below (FAO/WHO) permissible limits and could not cause any disease to man. Magnetized water increased tomato yield and did not add heavy metals to tomato fruit.

\section{Conclusions}

Combination of magnetized seed and magnetized water increased tomato yield by $44 \%$ while combination of nonmagnetized seed and magnetized water increased tomato yield by $27 \%$. Magnetized water had more influence on tomato yield than just magnetized the seed and irrigated with non-magnetized water. Magnetized water did not add heavy metals to the tomato which could be harmful to man and all the concentrations of heavy metals in the tomato were below FAO/WHO permissible limits. Magnetic treatment of irrigation water (magnetized water) is a non chemical method and environmentally-friendly that boosts crop yield should be adopted and use for crop production in Nigeria and other countries. More research should be conducted on the uptake of heavy metals by crops irrigated with magnetized water in areas having high concentration of heavy metals to know the effect of magnetized water and seed on uptake of heavy metals.

\section{References}

Aladjadjiyan A (2007). The use of physical methods for plant growing stimulation in Bulgaria. Journal of Central European Agriculture 8(3):369-380.

Alderfasi AA, Al-Suhaibani NA, Selim MM, Al-Hammad BA (2016). Using magnetic technologies in management of water irrigation programs under arid and semi-arid ecosystem. Journal of Advances in Plants and Agriculture Research 3(4):1-7.

Ali AME (2004). Effect of magnetizing irrigation water and seeds on the production of okra. MSc thesis submitted to the Department of Agricultural Engineering, University of Khartoum, Sudan.

Al-Khazan M, Abdullatif BM, Al-Assaf N (2011). Effects of magnetically treated water on water status, chlorophyll pigments and some elements content of jojoba (Simmondsia chinensis L.) at different growth stages. African Journal of Environmental Science and Technology 5(9):722731.

AOAC (2000). Official methods of analysis of the Association of Official Analytical Chemists. 15th Edition, Arlington, Virginia, USA.

Aoda MI, Fattah MA (2011). The interactive effects of water magnetic treatment and deficit irrigation on plant productivity and water use efficiency of corn (Zea mays L.). Iraqi Journal of Agricultural Sciences 42:164-179.

Babu C (2010). Use of magnetic water and polymer in agriculture. Tropical Research 08:806.

Chineke TC, ME Idinoba, OC Ajayi (2011). Seasonal evapotranspiration signatures under a changing land scope and ecosystem management in Nigeria: implication for agriculture and food security. American Journal ofScientific and Industrial Research 2(2):191-204.
Ejieji CJ, Adeniran KA (2009). Effect of water and fertilizer stress on the yield, fresh and dry matter production of grain amaranth. Australian Journal of Agricultural Engineering 1(1):18-24.

ELshokali AAM, Abdelbagi AM (2014). Impact of magnetized water on elements contents in plants seeds. International Journal of Scientific Research and Innovative Technology 1(4):12-21.

FAO (1985). Water quality for irrigation for agriculture. Irrigation Drainage Paper 29:1-130.

Hozayn M, AMS Abdul-Qados (2010). Irrigation with magnetized water enhances growth, chemical constituent and yield of chickpea (Circer arietinum L.). Agriculture and Biology Journal of North America 1(4):671-676.

Maheshwari RL, HS Grewal (2009). Magnetic treatment of irrigation water: its effects on vegetable crop yield and water productivity. Journal of Agricultural Water Management 96(8):1229-1236.

McMahon CA (2006). Investigation of the quality of water treated by magnetic fields. B.Eng Thesis University of Southern Queensland.

Mohammed AI, Ebead BM (2013). Effect of irrigation with magnetically treated water on faba bean growth and composition. International Journal of Agricultural Policy and Research 1(2):2440.

Montgomery DC, Runger GC, Hubele NF (1998). Engineering statistics. John Wiley and Sons, Inc. New York, pp 135-248.

Moussa HR (2011). The impact of magnetic water application for improving common bean (Phaseolusvulgaris L.) production. New York Science Journal 4(6):15-20.

Nagajyoti PC, Lee KD, Sreekanth TVM (2012). Heavy metals, occurrence and toxicity for plants: a review. Springer Journal of Environmental Chemistry Letter 8(3):199-216.

Ogunlela AO (2001). Stochastic analysis of rainfall event in Ilorin, Nigeria. Journal of Agricultural Research and Development 1(1):39-49.

Othman F, Sohaili J, Fausia Z (2009). Influence of magnetic treatment on the improvement of landfill leachate treatment. International Journal of Environment and Waste Management 4(3-4):433-444.

Podlesny J, Pietruszewski S, Podleoena A (2004). Efficiency of the magnetic treatment of broad bean seeds cultivated under experimental plot conditions. International Agrophysics 18(1):65-71.

Rawabdeh H, Shiyab S, Shibli R (2014). The effect of irrigation by magnetically chlorophyll and macroelements uptake of pepper (Capsicum annuum L.). Jordan Journal of Agricultural Sciences 10 (2):205-214.

Sani M (2003). The effect of moisture stress on yield of maize intercropped with cowpea. Unpublished B. Eng Project report submitted to the Department of Agricultural and Biosystems Engineering, University of Ilorin, Ilorin, Nigeria, pp 55.

Selim MM (2008). Application of magnetic technologies in correcting underground brackish water for irrigation in the arid and semi-arid ecosystem. The $3^{\text {rd }}$ International Conference on Water Resources and Arid Environments, and the $1^{\star}$ Arab Water Forum, held at King Fahd Cultural Centre, Riyadh, Saudi Arabia, pp 1-11.

SON (2007). Nigerian standard for drinkingwater quality.pp 1-30.

Taia W, Al-Zahrani H, Kotbi A (2007). The effect of static magnetic forces on water contents and photosynthetic pigments in sweet basil (Ocimum basilicum L.). Saudi Journal of Biological Sciences 14(1):103-107. 
Ufoegbune GC, Bello NJ, Dada OF, Eruola AC, Makinde AA, Amori AA (2012). Estimating water availability for agriculture in Abeokuta south western Nigeria. Global Journal of Science Frontier Research Agricultural and Veterinary Sciences 12(9):13-24.

WHO (2003). Guidelines for Drinking Water Quality, WHO, Geneva, pp 90-120.

Yano A, Ohashi Y, Hirasaki T, Fujiwara K (2004). Effects of $60 \mathrm{~Hz}$ magnetic field on photosynthetic uptake and early growth of radish seedlings. Bioelectromagnetics 25(8):572-581.
Yusuf KO, Ogunlela AO (2017a). Effects of magnetized water on the vegetative growth and yield of tomato. Agricultural Engineering International: CIGRJournal 19(1):1-8.

Yusuf KO, Ogunlela AO (2017b). Effect of magnetic treatment of water on evapotranspiration of tomato. Arid Zone Journal of Engineering Technologyand Environment 13(1):86-96.

Yusuf KO, Ogunlela AO (2016). Effect of magnetically treated water on the quality of tomato. Kathmandu University Journal of Science, Engineeringand Technology 12(2):29-33. 
YusufKO et al / Not Sci Biol, 2019, 11(1):122-129 
YusufKO et al / Not Sci Biol, 2019, 11(1):122-129 